\title{
Melilite-group minerals at Oldoinyo Lengai, Tanzania
}

\author{
Daniel Wiedenmann ${ }^{\mathrm{a}, \mathrm{b}, *}$, Jörg Keller ${ }^{\mathrm{c}}$, Anatoly N. Zaitsev ${ }^{\mathrm{d}, \mathrm{e}}$ \\ a Department of Geosciences, University of Fribourg, Pérolles, 1700 Fribourg, Switzerland \\ b EMPA, Swiss Federal Laboratories for Materials Testing and Research, Hydrogen and Energy, Überlandstrasse 129, 8600 Dübendorf, Switzerland \\ ' Institut für Geowissenschaften, Mineralogie-Geochemie, Universität Freiburg, Albertstrasse 23b, 79104 Freiburg, Germany \\ ${ }^{d}$ Department of Mineralogy, St. Petersburg State University, Universitetskaya nab. 7/9, St. Petersburg 199034, Russia \\ e Department of Mineralogy, The Natural History Museum, Cromwell Road, London, SW7 5BD, UK
}

\begin{abstract}
Oldoinyo Lengai and the volcanic centres of the Lake Natron-Engaruka province contain melilite as a widespread mineral. Extraordinarily Na-Al-rich melilites (up to 6 wt.\% $\mathrm{Na}_{2} \mathrm{O}$ and 9 wt.\% $\mathrm{Al}_{2} \mathrm{O}_{3}$ ) from recent explosive eruptions are among the most Na-rich ever reported. Their unusual mineral composition leads to optical properties with vivid birefringence colours of 2 nd order. The continuous variation in mineral composition from common åkermanite to $\mathrm{Na}$-Al-melilite (alumoåkermanite) is documented and reflects the whole peralkaline trend of Oldoinyo Lengai. The data presented allow the volcano's evolution from primitive olivine melilitites to highly evolved and peralkaline combeite-wollastonite nephelinites to be traced. Melilite compositions of Oldoinyo Lengai extend the magmatic field in the $\mathrm{Ca}_{2} \mathrm{Fe}\left(\mathrm{Si}_{2} \mathrm{O}_{7}\right)-\mathrm{Ca}_{2} \mathrm{Mg}\left(\mathrm{Si}_{2} \mathrm{O}_{7}\right)-(\mathrm{CaNa}) \mathrm{Al}$ $\left(\mathrm{Si}_{2} \mathrm{O}_{7}\right)$ end-member ternary compositional diagram.
\end{abstract}

\section{Introduction}

Oldoinyo Lengai is the only active carbonatite volcano in the world and is located in the Gregory Rift Valley, the northern Tanzanian sector of the East African Rift System, approximately $20 \mathrm{~km}$ south of Lake Natron (Fig. 1). The volcano is famous for its unique low-temperature and lowviscosity natrocarbonatites (Keller and Krafft, 1990; Peterson, 1990; Zaitsev et al., 2009). However, the $3000 \mathrm{~m}$ high cone is made up of predominantly silicate lavas and pyroclastics (Donaldson et al., 1987; Dawson et al., 1989; Dawson, 1998; Klaudius and Keller, 2006). Phonolites dominate the southerly Lengai I (Klaudius and Keller, 2006). The cone of the superimposed Lengai II developed after a major cone collapse of Lengai I (Klaudius and Keller, 2006), which occurred $\geq 10,000$ years BP (Klaudius and Keller, 2004; Kervyn et al., 2008) with related debris avalanche deposits extending about $25 \mathrm{~km}$ north into Lake Natron. Lengai II is characterized by its extremely peralkaline combeitewollastonite nephelinites, the most recent of which are melilite-bearing, especially the products of the 1940/41, 1966/67 and 2007/08 eruptions (Dawson et al., 1992; Mitchell and Dawson, 2007; Keller et al., 2010).

In historical times several explosive eruptions interrupted the natrocarbonatite effusive activity, erupting mixed silicate-carbonate ashes (Dawson et al., 1968, 1992) and carbonated silicate ashes and

\footnotetext{
* Corresponding author. EMPA, Division Hydrogen and Energy, Überlandstrasse 129, CH-8600 Dübendorf, Switzerland. Tel: +41 44 8234862; fax: + 41448234022

E-mail address: daniel.wiedenmann@gmail.com (D. Wiedenmann).
}

lapilli, as in the recent activity phase from September 4th of 2007 through the early summer of 2008 (Mitchell and Dawson, 2007; Vaughan et al., 2008; Reusser and Mattsson, 2008; Keller and Klaudius, 2008; Keller et al., 2010).

Melilite-bearing rocks are widespread, not only in the products of Oldoinyo Lengai itself but also from eruption centres in close vicinity to the volcano, and therefore play an important role in the petrological evolution of the volcanic centres of the Lake Natron-Engaruka province. High-Mg olivine melilitites closely related in time and space with the recent Oldoinyo Lengai evolution are described in detail (Dawson et al., 1985; Keller et al., 2006) as the only candidates in the area for primary melt compositions according to $\mathrm{Mg \#}$ and compatible trace elements. Based on the spatial relation to the main Lengai cone, we group Dorobo Cone, Oltatwa Crater, Kirurum Crater and the Nasira Cones as parasitic centres of Oldoinyo Lengai itself (Fig. 1). Armykon Hill, Lalarasi Cone and Loolmurwak Crater belong to the rift valley floor centres in the Gelai-Kerimasi-Lengai sector which is pockmarked and pierced by tuff cones and craters forming a monogenetic volcanic field of mostly olivine melilititic composition, some connected with lava flows (Dawson and Powell, 1969; Dawson et al., 1985; Keller et al., 2006; Nandedkar, 2008). Melilite-bearing lavas also occur in the rift escarpment lava series (Neukirchen et al., 2010) for which an eruption age between 3.2 and 1.2 Ma is suggested (Bagdasaryan et al., 1973; Dawson et al., 1992; Foster et al., 1997).

The peralkaline characteristics of the Oldoinyo Lengai evolution are already pronounced in the most primitive olivine melilitites 


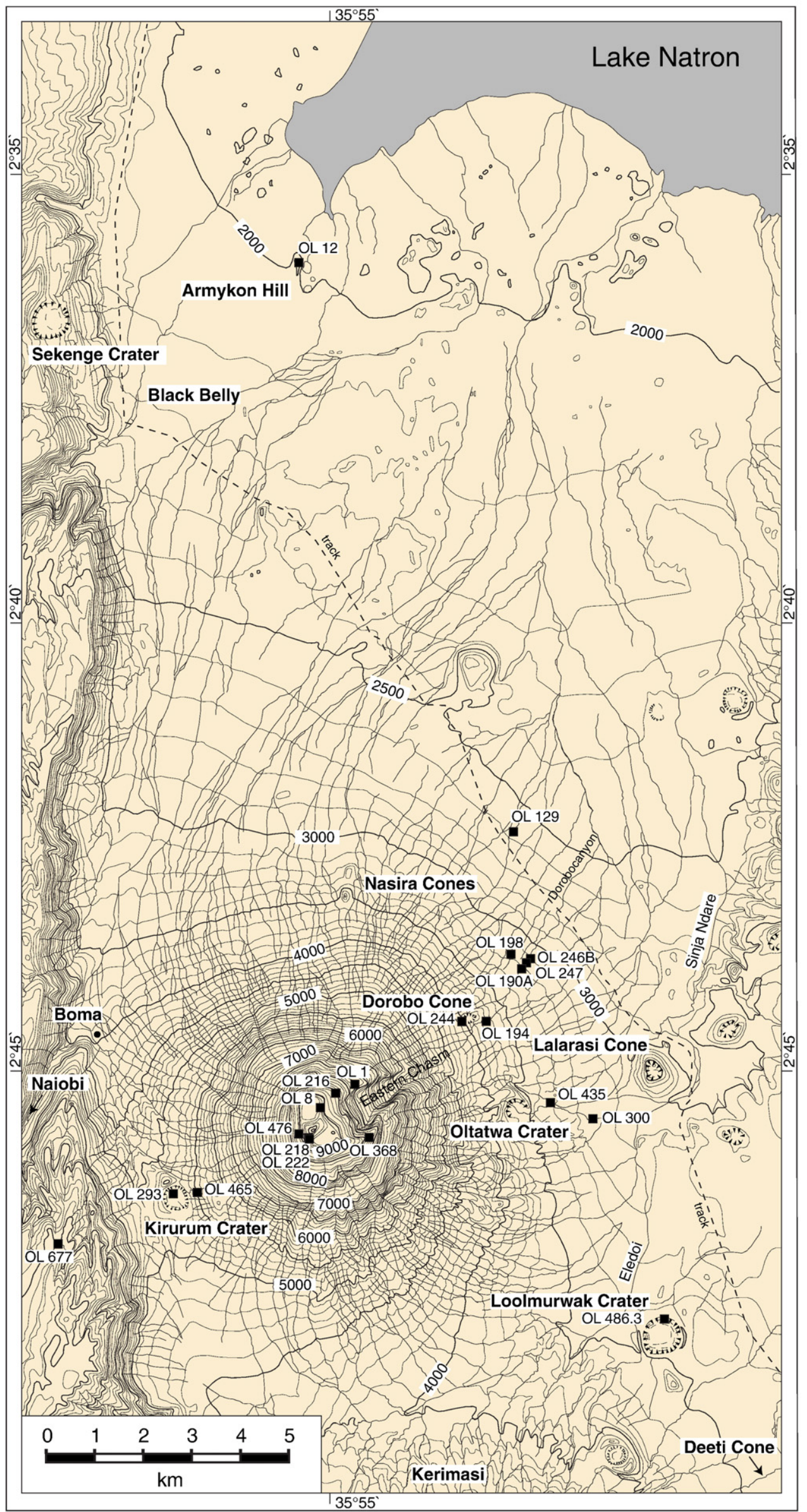


(Keller et al., 2006). However, a large compositional gap divides the highly evolved, low Mg\# phonolites and combeite-wollastonite nephelinites from the high-Mg\# primitive olivine melilitites (Klaudius and Keller, 2006).

\section{Occurence and petrography of melilitic rocks at Oldoinyo Lengai}

The dominant silicate volcanics of the cone of Oldoinyo Lengai, the phonolites of Lengai I, and the combeite-wollastonite nephelinites of the main Lengai II units are generally free of melilite (Dawson et al., 1996; Klaudius and Keller, 2006). However, our field studies have also revealed that melilite is an important constituent of a number of the younger rocks of Oldoinyo Lengai. Melilite occurs in the spherical lapilli and ashes of the 1966/67 and pre-1966 explosive eruptions, as well as in the ashes correlated with the 1940/1941 eruption (Wiedenmann, 2004; Keller et al., 2010). Idiomorphic melilite crystals up to $1.5 \mathrm{~cm}$ in size related to these deposits have been found in unconsolidated ashes in the stratigraphic higher levels of the volcano (Wiedenmann et al., 2009).

The melilitic rocks sampled for this study are classified as primitive olivine melilitites, intermediate melilite nephelinites, and highly evolved combeite- and wollastonite-bearing melilite nephelinites (Tables 1 and 2, Appendix A). The olivine melilitites (Mg\# from 70 to 59) have been described by Keller et al. (2006), including the high-Mg\# olivine-melilite nephelinite from Loolmurwak crater. Keller et al. (2006) also give chemical bulk rock composition for the olivine-free melilitites of Kirurum Crater, with Mg\# of 51.4 explained as fractionated from olivine melilitites (Keller et al., 2006, Table 1). The most primitive rocks found around Oldoiyo Lengai with $\mathrm{Mg \#}$ up to 70 are the olivine melilitites of the minor volcanic centres Dorobo Cone, and Lalarasi (Fig.1), all highly porphyritic volcanic rocks with forsteritic olivine and åkermanite as major phenocrysts and microphenocrysts phases, accompanied by perovskite and opaque spinel group minerals. Clinopyroxene is not a common phase in olivine melilitites, although sparse phenocrysts are found. Euhedral melilite appears with simple tabular habit showing well-developed $\{001\}$ faces and typical 1 st order anomalous blue interference colours (Keller et al., 2006).

The combeite-wollastonite nephelinites $(\mathrm{CWN})$ of the younger evolution of Oldoinyo Lengai are all highly evolved, with $\mathrm{Mg} \#<30$ (Donaldson et al., 1987; Klaudius and Keller, 2006). Also, the ashes and lapilli from the 1966/67 and pre-1966 explosive eruptions are characterized as melilite-bearing combeite-wollastonite nephelinites of the sub-recent Lengai II activity. They can be grouped under Dawson's Unit III, the young Black-Tuff-and-Agglomerates (Dawson, 1962; Dawson et al., 1989). The highly evolved, olivine-free melilite-nephelinitic spherical lapilli of the recent Lengai eruptions are melt-coated crystals with mainly $\mathrm{Na}$ - and Al-rich åkermanite and alumoåkermanite (Wiedenmann et al., 2009), nepheline, aegirine-augite, and occasionally combeite and wollastonite, forming the lapilli cores. Microcrysts of the matrix are nepheline, melilite, aegirine-augite, combeite, and spinel group minerals, and sporadic wollastonite, melanite, titanite, and sodalite. These melilites all show exceptionally vivid birefringence colours of 2 nd order in normal $30 \mu \mathrm{m}$ thin sections (Fig. 2).

The recent explosive activity of September 2007 and the following months produced juvenile lapilli and ashes with the composition defined as carbonated combeite-wollastonite-melilite nephelinite (Keller et al., 2010). A further unit with melilite as an essential component is Dawson`s Unit II: the Biotite-Pyroxene-Tuffs (Dawson, 1962; Dawson et al.,1989). These tuff breccias are characterized by up to several $\mathrm{cm}$ diameter megacrysts of olivine (forsterite), biotite (phlogopite), and pyroxene (diopside and aegirine-augite), referred to here as Olivine-Biotite-Pyroxene Tuffs or OBP tuffs (Wiedenmann,
Table 1

List of analysed melilite-bearing samples from Oldoinyo Lengai.

\begin{tabular}{|c|c|c|}
\hline Sample & Rock type & Locality \\
\hline \multicolumn{3}{|c|}{ Olivine melilitites } \\
\hline OL 12 & Lava flow & Armykon Hill; $2^{\circ} 35.999,35^{\circ} 54.654$ \\
\hline OL 198 & Lava clast from lapilli tuff & Dorobo Canyon (3800 ft.) \\
\hline OL 293 & $\begin{array}{l}\text { Lapilli tuff (fractionated } \\
\text { Mg\# 51) }\end{array}$ & Kirurum Crater (5250 ft.) \\
\hline \multicolumn{3}{|c|}{ Melilite nephelinites } \\
\hline OL 190A & Lapilli tuff & Dorobo Canyon (3210 ft.) \\
\hline OL 194 & Lapilli tuff (melt droplets) & Dorobo Cone (3430 ft.) \\
\hline OL 246B & Lava clast from lapilli tuff & Dorobo Canyon (3100 ft.) \\
\hline OL 247 & Lava clast from lapilli tuff & Dorobo Canyon (3150 ft.) \\
\hline OL 435 & Lava clast from lapilli tuff & East slope OL; $2^{\circ} 45.376,35^{\circ} 57.523$ \\
\hline OL 465 & Lapilli tuff & $\begin{array}{l}\text { South-west slope OL; } 2^{\circ} 46.360 \text {; } \\
35^{\circ} 53.536\end{array}$ \\
\hline OL 476 & Lapilli tuff & $\begin{array}{l}\text { Western slope OL; } 2^{\circ} 45.688 \text {, } \\
35^{\circ} 54.682\end{array}$ \\
\hline OL 486.3 & Lapilli tuff & $\begin{array}{l}\text { Loolmurwak Crater; } 2^{\circ} 47.747 \text {, } \\
35^{\circ} 58.733\end{array}$ \\
\hline OL 677 & Lapilli tuff & $\begin{array}{l}\text { Rift shoulder south-west OL; } \\
2^{\circ} 46.93435^{\circ} 51.971\end{array}$ \\
\hline \multicolumn{3}{|c|}{ Combeite nephelinites } \\
\hline Ol 1 & Lapilli tuff & North-east slope OL \\
\hline OL 8 & Lapilli tuff & $\begin{array}{l}\text { Northern crater, eastern rim } \\
\text { (9250 ft.) }\end{array}$ \\
\hline OL 129 & Ash tuff & North-east slope OL \\
\hline OL 216 & Lapilli tuff & North slope OL \\
\hline OL 218 & $\begin{array}{l}\text { Lapilli tuff, correlated } \\
\text { with } 1966 / 67\end{array}$ & $\begin{array}{l}\text { Western rim of south crater } \\
\text { (9350 ft.) }\end{array}$ \\
\hline OL 222 & $\begin{array}{l}\text { Lapilli tuff, correlated } \\
\text { with } 1966 / 67\end{array}$ & $\begin{array}{l}\text { Western rim of south crater } \\
\text { (9350 ft.) }\end{array}$ \\
\hline OL 244 & Ash tuff, & Dorobo Cone; $2^{\circ} 44.437,35^{\circ} 56.417$ \\
\hline OL 300 & Lapilli tuff & East slope OL; $2^{\circ} 41.156,35^{\circ} 56.416$ \\
\hline OL 368 & Melilite crystals from ash tuff & Southern crest of Eastern Chasm \\
\hline $\mathrm{XX}$ & $\begin{array}{l}\text { Melilite crystals isolated } \\
\text { from ash tuff }\end{array}$ & Lower eastern slope OL \\
\hline OL mel1\&2 & $\begin{array}{l}\text { Melilite crystals isolated } \\
\text { from ash tuff }\end{array}$ & Lower eastern slope OL \\
\hline
\end{tabular}

2004). Dawson (1998) relates these tuffs to parasitic cones of Oldoinyo Lengai. We confirm the wide distribution of black to greycoloured OBP tuffs in craters of the rift floor around Lengai, but have found coarse-grained and thick deposits of this lithology (OBP) high on the Lengai cone itself (Fig. 1, sample OL 476) at an altitude of $2750 \mathrm{~m}$ (approximately $9020 \mathrm{ft}$ ), and on the escarpment shoulder between the cone and the Maasai settlement Naiobi. It thus appears that similar OBP tuffs forming Unit II have been erupted from some of the parasitic vents as well as from the main Lengai crater. The darkcoloured tuffs are composed of juvenile magmatic lapilli in teardrop shape, highlighting the low-viscosity of the melts. They are highly porphyritic with melilite, olivine, biotite, diopside, aegirine-augite, and nepheline as major phenocrysts and microphenocrysts, together with garnet, perovskite, and spinel group minerals. Melilite appears in the typical tabular habit with anomalous blue and sporadic yellow interference colours implying the more evolved compositions (Fig. 2, Table 2).

Important to the context of this paper is the observation that juvenile components in the OBP breccias, olivine-biotite-pyroxene megacrystic lava blocks, and coated lapilli contain abundant melilite and are classified as olivine-bearing melilite nephelinites. The idiomorphic megacrysts occur in the matrix of the breccia as well as in the lava blocks. Their euhedral habit indicates that they are primary liquidus phases of the melilite-nephelinitic melt. The most important centres for these OBP melilite nephelinites are the parasitic Oltatwa 
Table 2

Representive EPMA major element analyses (wt.\%) of melilite from Oldoinyo Lengai.

\begin{tabular}{|c|c|c|c|c|c|c|c|c|c|c|c|c|c|c|c|}
\hline \multirow[t]{3}{*}{ Sample } & OL12 & OL198 & OL198 & OL246B & OL246B & OL465 & OL465 & OL476 & OL476 & OL216 & OL216 & OL244 & OL244 & OL mel2 & OL mel2 \\
\hline & $\mathrm{m} 1.3$ & $\mathrm{~m} 4.1$ & $\mathrm{~m} 4.2$ & $\mathrm{~m} 1.2$ & $\mathrm{~m} 3$ & $\mathrm{~m} 2.1$ & $\mathrm{~m} 2.2$ & $\mathrm{~m} 1.1$ & $\mathrm{~m} 1.2$ & $\mathrm{~m} 1.2$ & $\mathrm{~m} 2.2$ & $\mathrm{~m} 1.1$ & $\mathrm{~m} 1.2$ & $\mathrm{~m} 2.1$ & $\mathrm{~m} 2.2$ \\
\hline & Core & Rim & Core & & & Core & Rim & & & Core & Rim & Rim & Core & & Core \\
\hline Rock & Ol-mel & Ol-mel & Ol-mel & Mel-neph & Mel-neph & Mel-neph & Mel-neph & Mel-neph & Mel-neph & Cwn & Cwn & Cwn & Cwn & Cwn & Cwn \\
\hline \multicolumn{16}{|l|}{$w t . \%$} \\
\hline $\mathrm{SiO}_{2}$ & 43.29 & 43.90 & 43.28 & 43.88 & 44.22 & 43.93 & 43.99 & 43.77 & 43.80 & 43.11 & 43.52 & 42.30 & 42.93 & 43.19 & 43.38 \\
\hline $\mathrm{TiO}_{2}$ & 0.05 & 0.13 & 0.09 & b.d.l. & 0.06 & 0.03 & b.d.l. & 0.01 & 0.25 & 0.03 & 0.04 & 0.02 & 0.01 & 0.04 & 0.07 \\
\hline $\mathrm{Al}_{2} \mathrm{O}_{3}$ & 3.85 & 4.86 & 5.01 & 5.47 & 6.90 & 6.02 & 6.07 & 7.56 & 6.08 & 7.96 & 7.84 & 7.38 & 9.40 & 7.74 & 7.62 \\
\hline $\mathrm{Fe}_{2} \mathrm{O}_{3}$ & 0.56 & 1.44 & 1.61 & 0.64 & & 0.83 & 0.53 & 0.38 & 0.33 & 2.79 & 2.95 & 4.27 & 2.55 & 1.77 & 1.73 \\
\hline $\mathrm{FeO}$ & 2.90 & 2.22 & 1.75 & 3.11 & 3.97 & 2.69 & 3.02 & 5.50 & 2.99 & 5.08 & 4.55 & 5.74 & 4.01 & 4.30 & 4.21 \\
\hline $\mathrm{MnO}$ & 0.07 & 0.05 & 0.05 & 0.12 & 0.07 & 0.12 & 0.13 & 0.14 & 0.14 & 0.22 & 0.21 & 0.33 & 0.20 & 0.12 & 0.16 \\
\hline $\mathrm{MgO}$ & 9.83 & 9.66 & 9.50 & 8.18 & 7.33 & 7.95 & 8.10 & 5.42 & 8.10 & 4.04 & 4.27 & 2.98 & 3.54 & 5.42 & 5.44 \\
\hline $\mathrm{CaO}$ & 36.15 & 35.81 & 36.08 & 32.93 & 31.68 & 33.40 & 32.96 & 30.44 & 33.28 & 29.54 & 29.89 & 28.73 & 28.43 & 30.94 & 30.95 \\
\hline SrO & n.a. & 0.22 & 0.19 & 0.67 & 0.50 & 0.51 & 0.49 & 1.10 & 0.25 & 0.75 & 0.86 & 1.05 & 0.78 & 0.45 & 0.51 \\
\hline $\mathrm{Na}_{2} \mathrm{O}$ & 2.27 & 2.86 & 2.73 & 3.77 & 4.39 & 3.94 & 3.94 & 4.95 & 3.83 & 5.68 & 5.74 & 5.79 & 6.34 & 5.16 & 5.05 \\
\hline $\mathrm{K}_{2} \mathrm{O}$ & 0.16 & 0.15 & 0.16 & 0.18 & 0.19 & 0.14 & 0.14 & 0.12 & 0.22 & 0.09 & 0.10 & 0.10 & 0.10 & 0.10 & 0.09 \\
\hline Total: & 99.14 & 101.30 & 100.45 & 98.95 & 99.30 & 99.56 & 99.36 & 99.37 & 99.26 & 99.29 & 99.97 & 98.69 & 98.30 & 99.23 & 99.21 \\
\hline \multicolumn{16}{|l|}{ a.p.f.u. } \\
\hline $\mathrm{Si}$ & 1.990 & 1.971 & 1.960 & 2.015 & 2.016 & 2.001 & 2.006 & 2.012 & 1.998 & 1.991 & 1.994 & 1.986 & 1.986 & 1.993 & 2.000 \\
\hline $\mathrm{Ti}$ & 0.002 & 0.004 & 0.003 & & 0.002 & 0.001 & & & 0.009 & 0.001 & 0.001 & 0.001 & & 0.001 & 0.002 \\
\hline Al & 0.209 & 0.257 & 0.267 & 0.296 & 0.371 & 0.323 & 0.326 & 0.410 & 0.327 & 0.433 & 0.423 & 0.408 & 0.513 & 0.421 & 0.414 \\
\hline $\mathrm{Fe}^{3+}$ & 0.019 & 0.049 & 0.055 & 0.021 & & 0.029 & 0.019 & 0.014 & 0.011 & 0.097 & 0.102 & 0.151 & 0.089 & 0.06 & 0.060 \\
\hline $\mathrm{Fe}^{2+}$ & 0.112 & 0.083 & 0.066 & 0.120 & 0.151 & 0.102 & 0.114 & 0.211 & 0.114 & 0.196 & 0.174 & 0.225 & 0.155 & 0.166 & 0.162 \\
\hline $\mathrm{Mn}$ & 0.003 & 0.002 & 0.002 & 0.005 & 0.003 & 0.005 & 0.005 & 0.005 & 0.005 & 0.009 & 0.008 & 0.013 & 0.008 & 0.005 & 0.006 \\
\hline $\mathrm{Mg}$ & 0.674 & 0.647 & 0.641 & 0.560 & 0.498 & 0.540 & 0.551 & 0.371 & 0.551 & 0.278 & 0.292 & 0.209 & 0.244 & 0.373 & 0.374 \\
\hline $\mathrm{Ca}$ & 1.780 & 1.723 & 1.751 & 1.620 & 1.547 & 1.630 & 1.610 & 1.499 & 1.626 & 1.461 & 1.467 & 1.445 & 1.409 & 1.529 & 1.529 \\
\hline $\mathrm{Sr}$ & & 0.006 & 0.005 & 0.018 & 0.013 & 0.013 & 0.013 & 0.029 & 0.007 & 0.020 & 0.023 & 0.029 & 0.021 & 0.012 & 0.014 \\
\hline $\mathrm{Na}$ & 0.202 & 0.249 & 0.240 & 0.336 & 0.388 & 0.348 & 0.348 & 0.441 & 0.339 & 0.508 & 0.510 & 0.527 & 0.569 & 0.462 & 0.451 \\
\hline K & 0.009 & 0.009 & 0.009 & 0.011 & 0.011 & 0.008 & 0.008 & 0.007 & 0.013 & 0.005 & 0.006 & 0.006 & 0.006 & 0.006 & 0.005 \\
\hline Total: & 5.000 & 5.000 & 5.000 & 5.000 & 5.000 & 5.000 & 5.000 & 5.000 & 5.000 & 5.000 & 5.000 & 5.000 & 5.000 & 5.029 & 5.019 \\
\hline \multicolumn{16}{|l|}{ End-members } \\
\hline $\operatorname{SrNaAl}\left(\mathrm{Si}_{2} \mathrm{O}_{7}\right)$ & & 0.6 & 0.5 & 1.8 & 1.3 & 1.3 & 1.3 & 2.9 & 0.7 & 2.0 & 2.3 & 2.9 & 2.1 & 1.2 & 1.4 \\
\hline $\mathrm{Ca}_{2} \mathrm{Al}\left(\mathrm{AlSiO}_{7}\right)$ & 1.0 & 2.9 & 3.9 & & & & & & 0.2 & 0.8 & 0.6 & 1.4 & 1.4 & 0.7 & \\
\hline $\mathrm{Ca}_{2} \mathrm{Mn}\left(\mathrm{Si}_{2} \mathrm{O}_{7}\right)$ & 0.3 & 0.2 & 0.2 & 0.5 & 0.3 & 0.5 & 0.5 & 0.5 & 0.5 & 0.4 & 0.8 & 1.3 & 0.8 & 0.5 & 0.6 \\
\hline $\mathrm{Ca}_{2} \mathrm{Mg}\left(\mathrm{Si}_{2} \mathrm{O}_{7}\right)$ & 67.4 & 64.7 & 64.1 & 56.0 & 48.9 & 54.0 & 55.1 & 37.1 & 55.1 & 27.8 & 29.2 & 20.9 & 24.4 & 37.1 & 37.3 \\
\hline $\mathrm{CaNaAl}\left(\mathrm{Si}_{2} \mathrm{O}_{7}\right)$ & 18.9 & 19.3 & 18.4 & 27.8 & 35.8 & 31.0 & 31.3 & 38.1 & 31.6 & 39.7 & 38.8 & 35.1 & 46.4 & 39.3 & 39.9 \\
\hline $\mathrm{CaNaFe}^{3+}\left(\mathrm{Si}_{2} \mathrm{O}_{7}\right)$ & 1.3 & 4.9 & 5.1 & 2.1 & 0.0 & 2.5 & 1.9 & 1.4 & 1.1 & 9.1 & 9.9 & 14.7 & 8.4 & 5.5 & 3.7 \\
\hline $\mathrm{Ca}_{2} \mathrm{Fe}\left(\mathrm{Si}_{2} \mathrm{O}_{7}\right)$ & 10.2 & 6.2 & 6.6 & 9.5 & 10.2 & 10.2 & 8.3 & 17.6 & 9.2 & 19.6 & 17.4 & 22.5 & 15.5 & 15.2 & 16.1 \\
\hline Not assigned & 0.9 & 1.2 & 1.2 & 2.3 & 3.5 & 0.5 & 1.6 & 2.4 & 1.6 & 0.6 & 1.0 & 1.2 & 1.0 & 0.6 & 1.1 \\
\hline Total & 100.0 & 100.0 & 100.0 & 100.0 & 100.0 & 100.0 & 100.0 & 100.0 & 100.0 & 100.0 & 100.0 & 100.0 & 100.0 & 100.0 & 100.0 \\
\hline
\end{tabular}

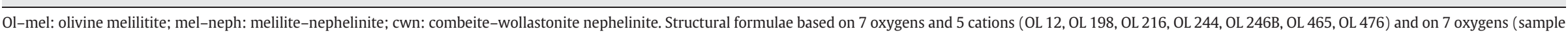
OL mel2). b.d.l. - below detection limit. n.a. - not analysed. 

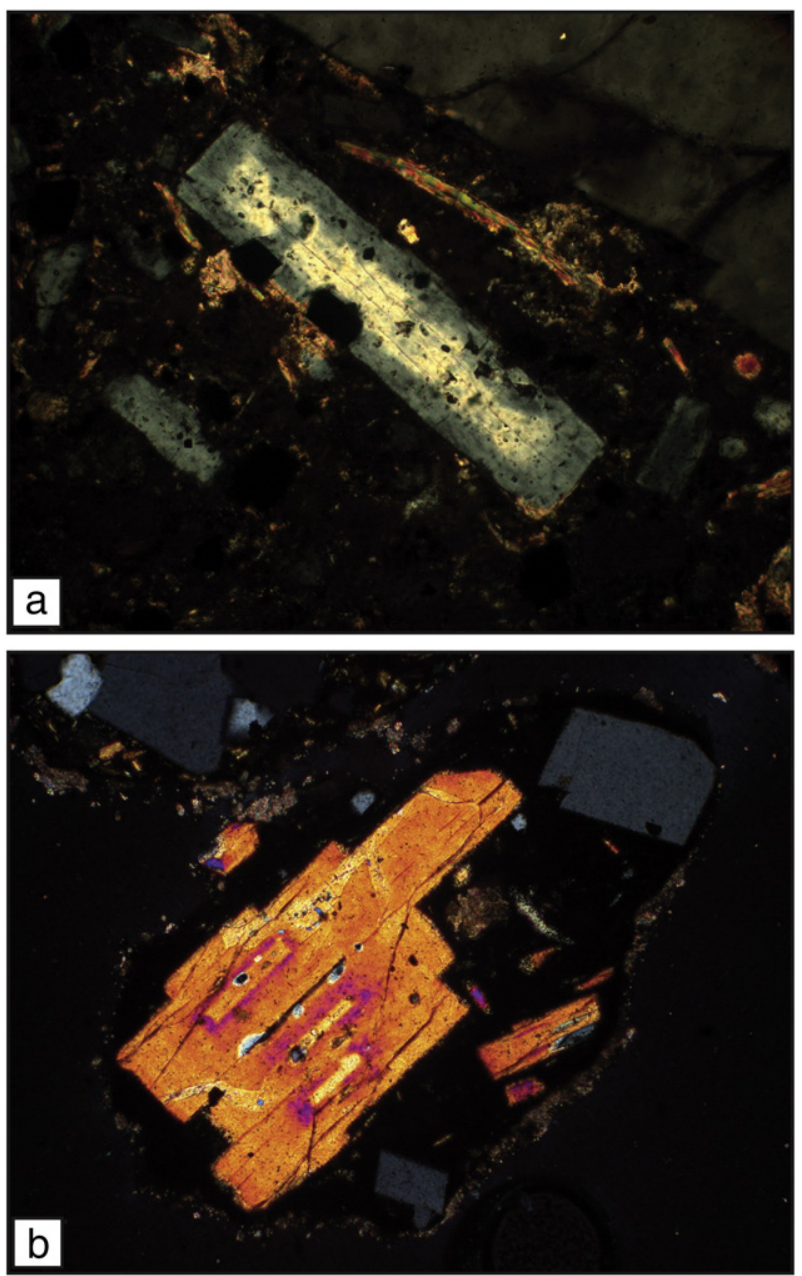

Fig. 2. Thin section photographs of Oldoinyo Lengai melilites. (a) Inverse zoned åkermanite phenocryst (Na-rich core) from olivine-bearing melilite nephelinite OL 246B showing anomalous blue to yellow birefringence colours. (b) Alumoåkermanite phenocryst showing oscillatory zoning (melilite nephelinite OL 216) with birefringence colours of 2nd order. Crossed nicols. Field of view is $1 \times 1.5 \mathrm{~mm}$.

Crater on the lower east flank of the cone (Wiedenmann, 2004; Keller et al., 2006) and the Loolmurwak explosion crater at the southeastern foot of Oldoinyo Lengai (Fig. 1), and also numerous of the EngarukaNatron tuff cones and centres, as for instance the Deeti Cone (Dawson and Powell, 1969; Johnson et al., 1997) which has not yet been explored in more detail. Sekenge Crater, located $15 \mathrm{~km}$ north of Lengai, is a maar-type explosion crater carved in the escarpment above Engare Sero village and has erupted biotite-bearing melilitite tuffs (Finkenbein, 2005; Neukirchen et al., 2010).

\section{Analytical techniques}

\subsection{Electron microprobe}

Electron microprobe analyses were performed by the wavelengthdispersive spectrometry technique using a Cameca SX-100 microprobe located at the Department for Geosciences, University of Freiburg, Germany. Operating conditions were $15 \mathrm{kV}$ and $20 \mathrm{nA}$, with a spot size of $1 \mu \mathrm{m}$ on single point measurements. Well characterized minerals and synthetic materials were used as standards: wollastonite $(\mathrm{Si}, \mathrm{Ca})$, rutile (Ti), anorthite $(\mathrm{Al})$, fayalite $(\mathrm{Fe})$, rhodonite $(\mathrm{Mn})$, celestine $(\mathrm{Sr})$, albite $(\mathrm{Na})$, orthoclase $(\mathrm{K})$, and $\mathrm{MgO}(\mathrm{Mg})$. Additional melilite analyses were obtained using a Jeol Superprobe 8800 at the Swiss Federal Laboratories for Materials Testing and Research (EMPA) in Dübendorf, Switzerland.

\subsection{Mössbauer spectroscopy}

Mössbauer spectra were obtained through the courtesy of Catherine McCammon (Bayreuth) on two melilite megacrysts from the recent pyroclastic rocks at Oldoinyo Lengai. The analyses refer to samples "OL mel1" and "OL mel2" in Table 2. For both samples, $\mathrm{Fe}^{3+} /$ $\left(\mathrm{Fe}^{2+}+\mathrm{Fe}^{3+}\right)$ is $0.27 \pm 0.03$ (Wiedenmann et al., 2009). These ratios are very similar to published values (Seifert and Federico, 1987).

\section{Compositional variation of melilite}

A limited number of melilite compositions from the Oldoinyo Lengai area were published by Donaldson and Dawson (1978), Hay (1978, 1989) Dawson et al. (1985, 1989), Keller and Krafft (1990), Dawson (1998), Petibon et al. (1998), Wiedenmann (2004), Keller et al. (2006), Mitchell and Dawson (2007). In this work we present over 200 additional melilite microprobe analyses (Table 2, Appendix A) ranging from $\mathrm{Na}$-Al-bearing melilite from olivine melilitites to Alrich, high-Na melilites from the recent combeite-wollastonite nephelinites. Representative compositions of melilites from the Lengai cone itself and the volcanic centres around are given in Table 2.

Melilite-group minerals have the general formula $\mathrm{X}_{2} \mathrm{~T} 1(\mathrm{~T} 2)_{2} \mathrm{O}_{7}$ $\left(\mathrm{X}=\mathrm{Ca}, \mathrm{Sr}, \mathrm{Na} ; \mathrm{T} 1=\mathrm{Mg}, \mathrm{Fe}^{2+}, \mathrm{Al}, \mathrm{Fe}^{3+} ; \mathrm{T} 2=\mathrm{Si}, \mathrm{Al}\right.$ ). The T2-site is mainly occupied by Si excluding a remarkable gehlenite-component, which is in agreement with other volcanic melilites (Sahama, 1967). The T1-site is mainly occupied by $\mathrm{Al}, \mathrm{Fe}^{2+}$, and $\mathrm{Mg}$, the X-site by $\mathrm{Ca}$ and $\mathrm{Na}$. The estimation of $\mathrm{Fe}^{2+}$ and $\mathrm{Fe}^{3+}$ concentration was based on the procedure of Droop (1987). Melilite data are plotted in terms of the components $\mathrm{Ca}_{2} \mathrm{Mg}\left(\mathrm{Si}_{2} \mathrm{O}_{7}\right), \mathrm{Ca}_{2} \mathrm{Fe}\left(\mathrm{Si}_{2} \mathrm{O}_{7}\right)$, and the sum of $(\mathrm{CaNa}) \mathrm{Al}$ $\left(\mathrm{Si}_{2} \mathrm{O}_{7}\right)$ and $(\mathrm{CaNa}) \mathrm{Fe}^{3+}\left(\mathrm{Si}_{2} \mathrm{O}_{7}\right)$ (Fig. 3).

Due to the particularly high Al-content, the evolved melilites show a considerable $(\mathrm{CaNa})\left(\mathrm{Al}, \mathrm{Fe}^{3+}\right)\left(\mathrm{Si}_{2} \mathrm{O}_{7}\right)$ component (Wiedenmann et al., 2009). The exceptionally high-Na- and Al-content of the evolved melilites extends the field for magmatic melilite of Velde and Yoder (1977). The presented data show a continuous compositional variation from åkermanite to alumoåkermanite (Fig. 4).

Melilite from olivine melilitites is characterized by high $\mathrm{MgO}$ (up to 10 wt.\%), low $\mathrm{FeO}_{\text {tot }}(<4 \mathrm{wt} . \%)$, moderate $\mathrm{Na}_{2} \mathrm{O}(<4 \mathrm{wt} . \%)$, and $\mathrm{Al}_{2} \mathrm{O}_{3}$ (up to 6 wt.\%). Compositions from melilite nephelinites show lower $\mathrm{MgO}$ (down to $<5 \mathrm{wt} . \%$ ) but higher $\mathrm{FeO}_{\text {tot }}$ (up to $10 \mathrm{wt} . \%$ ) and

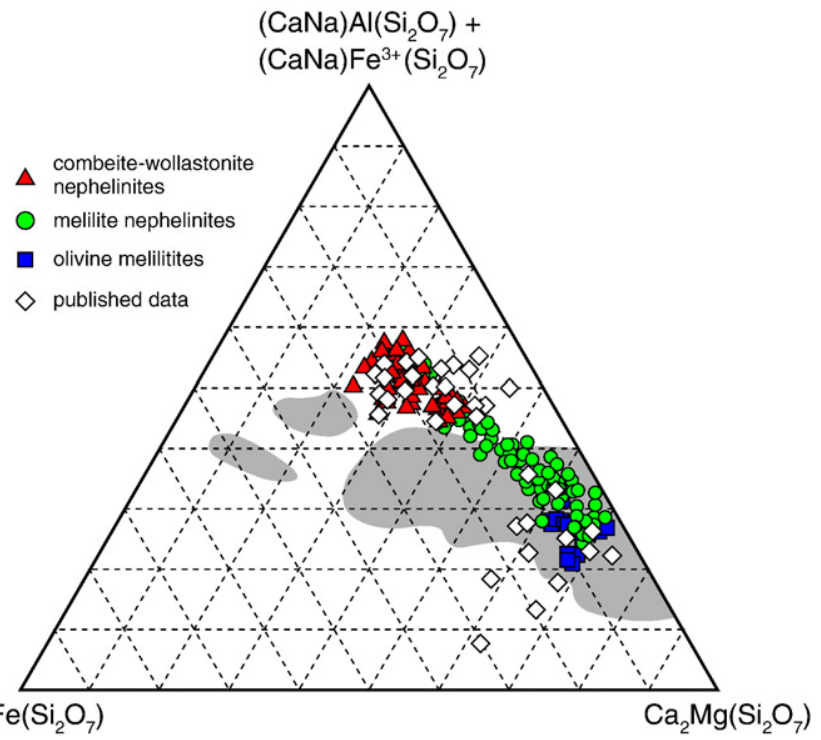

Fig. 3. Classification of Oldoinyo Lengai melilites in terms of the components $\mathrm{Ca}_{2} \mathrm{Mg}$ $\left(\mathrm{Si}_{2} \mathrm{O}_{7}\right),(\mathrm{CaNa})\left(\mathrm{Al}, \mathrm{Fe}^{3+}\right)\left(\mathrm{Si}_{2} \mathrm{O}_{7}\right)$, and $\mathrm{Ca}_{2} \mathrm{Fe}\left(\mathrm{Si}_{2} \mathrm{O}_{7}\right)$. The high sodium content of the Lengai melilites extends the grey-coloured field for magmatic melilite of Velde and Yoder (1977). References for published data in the text. 


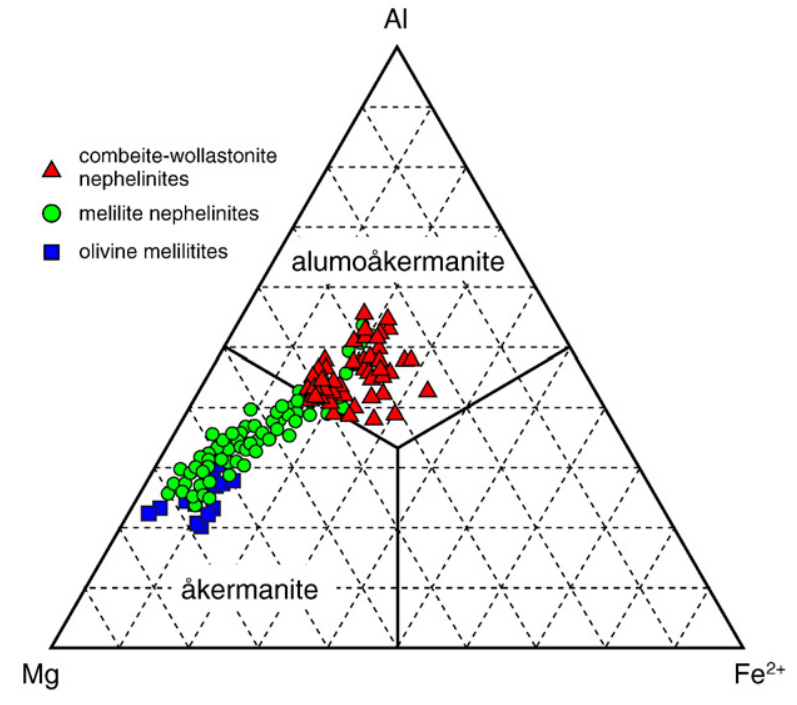

Fig. 4. Composition diagram (T1-site, at.\%) of melilite from Oldoinyo Lengai in terms of åkermanite and alumoåkermanite based on the dominant-constituent rule considering $\mathrm{Al}^{3+}$ as the only trivalent cation on the T1-site. The data show the continuous compositional variation from åkermanite to alumoåkermanite.

remarkably high $\mathrm{Na}_{2} \mathrm{O}$ (up to 6 wt.\%). While most of the melilite crystals from olivine melilitites are unzoned and fall within a narrow compositional range, phenocrysts and microphenocrysts of the melilite nephelinites show normal, inverse, and oscillatory zoning, covering all compositions between sodic åkermanite and alumoåkermanite. This complex zoning pattern indicates changes of crystallization conditions, probably caused by repeated magma pulses added to the system.
With decreasing Mg\#, Na increases and Ca decreases considerably and the X-site is completely occupied by $\mathrm{Ca}$ and $\mathrm{Na}$ (Fig. 5a and b). In general, Al corresponds to decreasing Mg\# and increasing Na (Fig. 5c). Mössbauer data (Wiedenmann et al., 2009) show an average content of 1.84 wt.\% $\mathrm{Fe}_{2} \mathrm{O}_{3}$ and 4.45 wt.\% $\mathrm{FeO}$ in the measured crystals. The location of ferric iron in synthetic soda melilite was determined by Akasaka et al. (2005) and Seifert (1988) by using the Mössbauer and Rietveld methods, showing $\mathrm{Fe}^{3+}$ on the T1-site of the crystal structure. The tendency for more than 5 cations in the calculated melilite formula and the Mössbauer results suggests a significant amount of ferric Fe, especially for the high-Na melilites. The ratio of $\left(\mathrm{Al}+\mathrm{Fe}^{3+}\right)$ in the T1-site to $\mathrm{Na}$ in the $\mathrm{X}$-site is $1: 1$ (Fig. $5 \mathrm{~d}$ ).

\section{Discussion and conclusions}

Nephelinites can be produced from a parental mantle-derived olivinemelilitic melt by the fractionation of olivine, pyroxene, phlogopite, and melilite (Onuma and Yagi, 1967; Yagi and Onuma, 1978; Peterson and Kjarsgaard, 1995; Dawson, 1998; Dawson, 2008). The olivine melilitites in the vicinity of Oldoinyo Lengai occur late in the evolution (Keller et al., 2006) and are of minor volume compared to the bulk of evolved phonolites and nephelinites at Oldoinyo Lengai. For the entire evolution of the Younger Extrusives in northern Tanzania, Dawson (2008) considered a repeated or cyclic occurrence of primary mantle melts as the olivine melilitites and olivine nephelinites in the Lake Natron-Engaruka province. Primary magma compositions for the initial phases of the Lengai evolution are not found in direct relationship with the volcano. Moreover, the compositional gap between olivine melilitites and nephelinites and the different isotopic signature show a complex petrological relationship (Dawson, 2008; Keller et al., 2006). Testimony of the complex fractionation processes deeper in the crust can be seen in the large
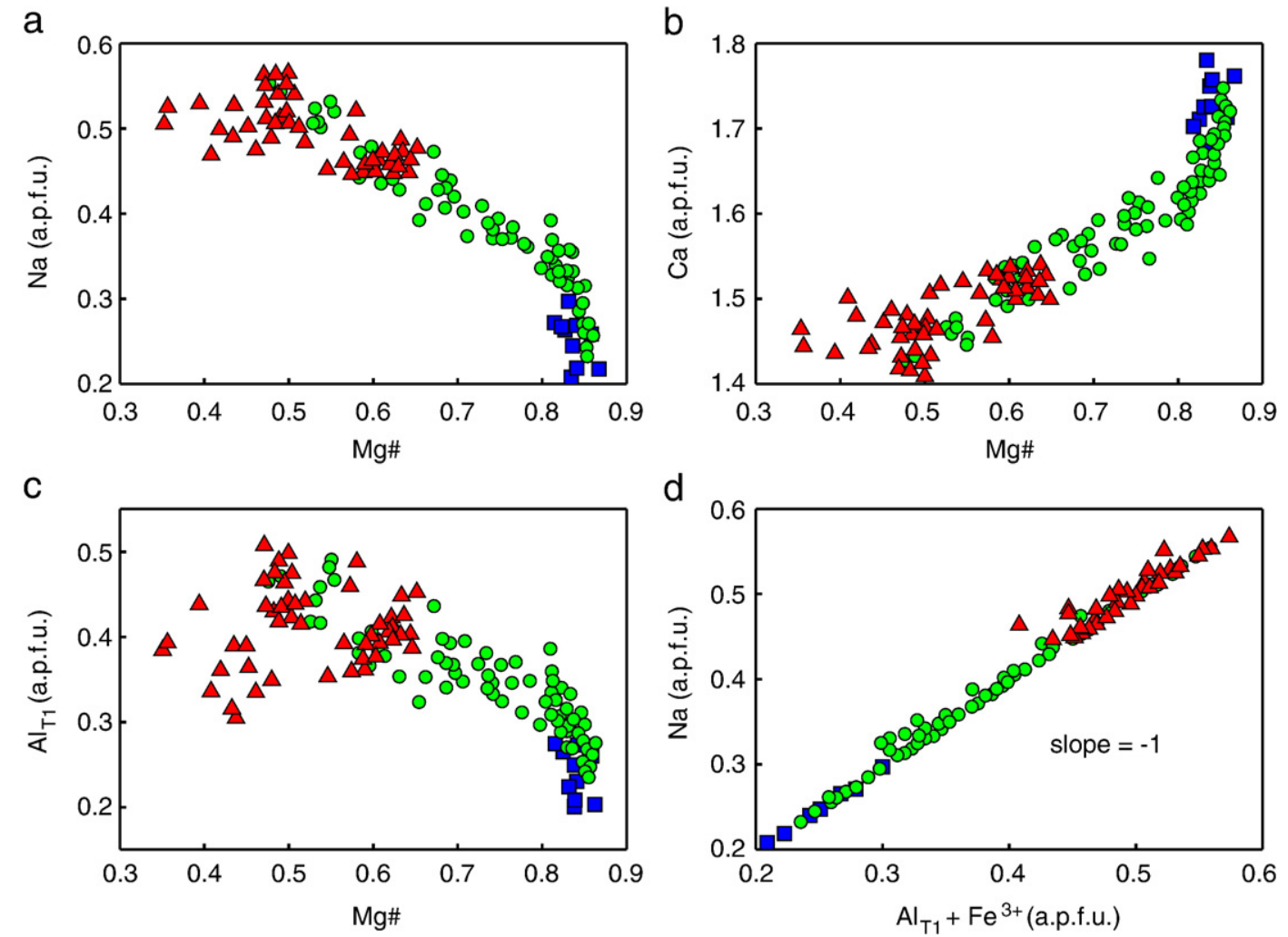

olivine melilitites

- melilite nephelinites

$\Delta$ combeite-wollastonite nephelinites

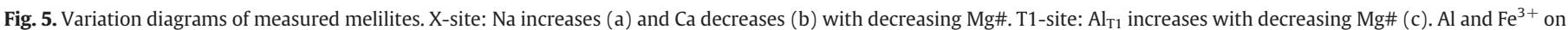
the T1-site are in a 1:1 ratio with $\mathrm{Na}(\mathrm{d})$. 
amounts of plutonic xenoliths, subvolcanic volcanics and cumulates ejected with the explosive eruptions (Dawson, 1962; 2008).

The volcano's temporal evolution from primitive olivine melilitites to highly evolved melilite- and combeite-bearing nephelinites is mirrored in the continuous chemical variation of the analysed melilites (Figs. 3, 4, and 5). This covers the distinct peralkaline trend of the volcano (Klaudius and Keller, 2006), which is already recognised in the primary olivine melilitic melts and culminates in the appearance of combeite in the younger and highly evolved melilite-bearing nephelinites (Keller et al., 2010). The peralkaline trend is traced in the melilite composition by an increasing $\mathrm{Na}$ - and Al-content with decreasing Mg\# (Fig. 5).

Our investigations show not only that most of the parasitic centres on the slopes of Oldoinyo Lengai are melilitic, but also that the main Lengai crater itself erupted melilite-bearing volcanics. The close relation in time and space between the melilitic rocks of the rift-sector and the peralkaline evolution of Lengai II (Dawson et al., 1985; Peterson and Kjarsgaard, 1995; Johnson et al., 1997; Keller et al., 2006) and the continuous chemical variation of the analysed melilites together suggest a close genetic relationship between the predominantly olivine-melilitic centres of the rift, the parasitic centres on the slopes of Oldoinyo Lengai, and meliliticnephelinitic products of the main Lengai crater. Moreover, the appearance of combeite in the spherical lapilli of the recent eruptions also suggests a close genetic relationship of the evolved $\mathrm{Na}$-Al-melilite-bearing nephelinites with the combeite- and wollastonite-bearing melilite nephelinites group of Lengai II (Klaudius and Keller, 2006).

\section{Acknowledgements}

We owe thanks to Jurgis Klaudius and Burra Ami Gadiye for assistance in the field, and Catherine McCammon (University of Bayreuth) for providing Mössbauer Spectroscopy. We also thank Hiltrud Müller-Sigmund for support with EPMA. We are grateful to Roger Mitchell and Colin H. Donaldson for their valuable insights, and to Alan Woolley and Honza Catchpole for their input and linguistic help. This work was supported by Deutsche Forschungsgemeinschaft (grant KE 136/40) and the Alexander von Humboldt Stiftung.

\section{Appendix A. Supplementary material}

Supplementary data associated with this article can be found, in the online version, at doi:10.1016/j.lithos.2010.04.002.

\section{References}

Akasaka, M., Nagashima, M., Makino, K., Ohashi, H., 2005. Distribution of $\mathrm{Fe}^{3+}$ in a synthetic (Ca,Na) $)_{2}\left(\mathrm{Mg}, \mathrm{Fe}^{3+}\right) \mathrm{Si}_{2} \mathrm{O}_{7}$-melilite: ${ }^{57} \mathrm{Fe}$ Mössbauer and X-ray Rietveld studies. Journal of Mineralogical and Petrological Sciences 100, 229-236.

Bagdasaryan, G.P., Gerasimovskiy, V.I., Polyakov, A.I., Gukasyan, R.K., Vernadskiy, V.I., 1973. Age of volcanic rocks in the rift zones of East Africa. Geochemistry International 10, 66-71.

Dawson, J.B., 1962. The geology of Oldoinyo Lengai. Bulletin of Volcanology 24, 348-387. Dawson, J.B., 1998. Peralkaline nephelinite-natrocarbonatite relationships at Oldoinyo Lengai, Tanzania. Journal of Petrology 39, 2077-2094.

Dawson, J.B., 2008. The Gregory Rift Valley and Neogene-Recent Volcanoes of Northern Tanzania. Geological Society London Memoir No. 33. 98 pages.

Dawson, J.B., Bowden, P., Clark, G.C., 1968. Activity of the carbonatite volcano Oldoinyo Lengai. Geologische Rundschau 57, 865-879.

Dawson, J.B., Powell, D.G., 1969. The Natron-Engaruka explosion crater area, Northern Tanzania. Bulletin of Volcanology 33, 761-817.

Dawson, J.B., Smith, J.V., Jones, A.P., 1985. A comparative study of bulk rock and mineral chemistry of olivine melilitites and associated rocks from East and South Africa. Neues Jahrbuch Mineralogischer Abhandlungen 152, 143-175.

Dawson, J.B., Smith, J.V., Steele, I.M., 1989. Combeite $\left(\mathrm{Na}_{2.33} \mathrm{Ca}_{1.74}\right.$ others $\left.{ }_{0.12}\right) \mathrm{Si}_{3} \mathrm{O}_{9}$ from Oldoinyo Lengai, Tanzania. Journal of Geology 97, 365-372.

Dawson, J.B., Smith, J.V., Steele, I.M., 1992. 1966 ash eruption of the carbonatite volcano Oldoinyo Lengai: mineralogy of lapilli and mixing of silicate and carbonate magmas. Mineralogical Magazine 56, 1-16.

Dawson, J.B., Pyle, D.M., Pinkerton, H., 1996. Evolution of natrocarbonatite from a wollastonite nephelinite parent: evidence from the June 1993 eruption of Oldoinyo Lengai, Tanzania. Journal of Geology 104, 41-54.

Donaldson, C.H., Dawson, J.B., 1978. Skeletal crystallization and residual glass compositions in a cellular alkalic pyroxenite nodule from Oldoinyo Lengai. Contributions to Mineralogy and Petrology 67, 139-149.
Donaldson, C.H., Dawson, J.B., Kanaris-Sotiriou, R., Batchelor, R.A., Walsh, J.N., 1987. The silicate lavas of Oldoinyo Lengai, Tanzania. Neues Jahrbuch fuer Mineralogie, Abhandlungen 156, 246-279.

Droop, G.T.R., 1987. A general equation for estimating $\mathrm{Fe}^{3+}$ concentrations in ferromagnesian silicates and oxides from microprobe analyses, using stoichiometric criteria. Mineralogical Magazine 51, 431-435.

Foster, A., Ebinger, C., Mbede, E., Rex, D., 1997. Tectonic development of the northern Tanzanian sector of the East African Rift System. Journal of the Geological Society (London) 154, 689-700.

Finkenbein, T., 2005. Petrologie und Vulkanologie der Riftflanke und des Sekenge Kraters bei Engare Sero, East African Rift, Tanzania. Diploma thesis, University of Freiburg, $140 \mathrm{pp}$.

Hay, R.L., 1978. Melilite-carbonatite tuffs in the Laetolil Beds of Tanzania. Contributions to Mineralogy and Petrology 67, 357-367.

Hay, R.L., 1989. Holocene carbonatite-nephelinite tephra deposits of Oldoinyo Lengai, Tanzania. Journal of Volcanology and Geothermal Research 37, 77-914.

Johnson, L.H., Jones, A.P., Church, A.A., Taylor, W.R., 1997. Ultramafic xenoliths and megacrysts from a melilite tuff cone, Deeti, northern Tanzania. Journal of African Earth Sciences 25, 29-42.

Keller, J., Krafft, M., 1990. Effusive natrocarbonatite activity of Oldoinyo Lengai, June 1988. Bulletin of Volcanology 52, 629-645.

Keller, J., Zaitsev, A.N., Wiedenmann, D., 2006. Primary magmas at Oldoinyo Lengai: the role of olivine melilitites. Lithos 91, 150-172.

Keller, J., Klaudius, J., 2008. Fundamental changes in the activity of the natrocarbonatite volcano Oldoinyo Lengai, Tanzania: new magma composition with the 4th September 2007 paroxysm. IAVCEI General Assembly Iceland 2008. Abstract.

Keller, J. Klaudius, J. Kervyn, M., Ernst, G.G.J., Mattson, H.B., 2010. Fundamental changes in the activity of the natrocarbonatite volcano Oldoinyo Lengai, Tanzania: new magma composition during the 2007-2008 explosive eruptions. Bulletin of Volcanology (submitted).

Kervyn, M., Klaudius, J., Keller, J., Mbede, E., Jacobs, P., Ernst, G.G.J., 2008. Remote sensing study of sector collapses and debris-avalanche deposits at Oldoinyo Lengai and Kerimasi volcanoes, Tanzania. International Journal of Remote Sensing 29 (22), 6565-6595.

Klaudius, J., Keller, J., 2004. Quaternary debris avalanche deposits at Oldoinyo Lengai, Tanzania. IAVCEI General Assembly, Pucon, Chile. Abstract.

Klaudius, J., Keller, J., 2006. Peralkaline silicate lavas at Oldoinyo Lengai, Tanzania. Lithos 91, 173-190.

Mitchell, R.H., Dawson, J.B., 2007. The $24^{\text {th }}$ September 2007 ash eruption of the carbonatite volcano Oldoinyo Lengai, Tanzania: mineralogy of the ash and implications of a new hybrid magma type. Mineralogical Magazine 71, 483-492.

Nandedkar, R.H., 2008. Petrology of the Lake Natron - Engaruka monogenetic volcanic field, Gregory Riftin Northern Tanzania (East African Rift System). Master thesis, ETH Zurich, Switzerland, 129 pp.

Neukirchen, F. Finkenbein, T. Keller, J. 2010. The lava sequence of the East African Rift Escarpment in the Oldoinyo Lengai - Lake Natron sector, Tanzania. Journal of African Earth Sciences accepted 2009 JAES 1104.

Onuma, K., Yagi, K., 1967. The system diopside-åkermanite-nephelinite. American Mineralogist 52, 227-243.

Peterson, T.D., 1990. Petrology and genesis of natrocarbonatite. Contributions to Mineralogy and Petrology 105, 143-155.

Peterson, T.D., Kjarsgaard, B.A., 1995. What are the parental magmas at Oldoinyo Lengai? In: Bell, K., Keller, J. (Eds.), Carbonatite Volcanism: Oldoinyo Lengai and the Petrogenesis of Natrocarbonatites. IAVCEI Proceedings in Volcanology, vol. 4. Springer Verlag, Berlin, pp. 148-162.

Petibon, C.M., Kjarsgaard, D.A., Jenner, G.A., Jackson, S.E., 1998. Phase relationships of a silicate-bearing natrocarbonatite from Oldoinyo Lengai at 20 and 100 MPa. Journal of Petrology 39, 2137-2151.

Reusser, E., Mattsson, H., 2008. Natrocarbonatitic tephrafall from the explosive eruption of Oldoinyo Lengai in September 2007. 6th Swiss Geoscience Meeting, Lugano, Switzerland 2008. Abstract 2.24, p. 96.

Sahama, T.G., 1967. Iron content of melilite. Societé Géolgique de Finlande 39, 17-28.

Seifert, F., 1988. Recent advantages in the mineralogical applications of the ${ }^{57} \mathrm{Fe}$ Mössbauer effect. In: salja, E.K.H. (Ed.), Proceedings of the NATO Advanced Study Institute on Physical Properties and Thermodynamic Behavior of Minerals. D. Reidel Publishing Company, Dordrecht, Netherlands, p. 707. 687-703.

Seifert, F., Federico, M., 1987. ${ }^{57} \mathrm{Fe}$ Mössbauer spectroscopy of natural melilites. Rendiconti Della Societa Italiana Di Mineralogia e Petrologia 42, 3-11.

Vaughan, R.G., Kervyn, M., Realmuto, V., Abrams, M., Hook, S.J., 2008. Satellite measurements of recent volcanic activity at Oldoinyo Lengai, Tanzania. Journal of Volcanology and Geothermal Research 173 (3-4), 196-206.

Velde, D., Yoder, H.S., 1977. Melilite and melilite-bearing igneous rocks - Carnegie Institution of Washington: Year Book, 76, pp. 478-485.

Wiedenmann, D., 2004. Vulkanologische Stellung und petrologische Interpretation der Biotit-Pyroxen-Olivin-Tuffe am Oldoinyo Lengai, Tansania. Diploma thesis, Freiburg im Breisgau, Germany, 89 pp.

Wiedenmann, D., Zaitsev, A.N., Britvin, S.N., Krivovichev, S.V., Keller, J., 2009. Alumoåkermanite, $(\mathrm{Ca}, \mathrm{Na})_{2}\left(\mathrm{Al}, \mathrm{Mg}, \mathrm{Fe}^{2+}\right)\left(\mathrm{Si}_{2} \mathrm{O}_{7}\right)$, a new mineral from the active carbonatite-nephelinite-phonolite volcano Oldoinyo Lengai, northern Tanzania. Mineralogical Magazine 73 (3), 373-384.

Yagi, K., Onuma, K., 1978. Genesis and differentation of nephelinitic magma. Bulletin of Volcanology 41 (4), 466-472.

Zaitsev, A.N., Keller, J., Spratt, J., Jeffries, T.E., Sharygin, V.V., 2009. Chemical composition of nyerereite and gregoryite from natrocarbonatites of Oldoinyo Lengai volcano, Tanzania. Geology of Ore Deposits 51 (7), 608-616. 